\title{
Indigenous Security Measures in Can-eo and Talubin, Northern Philippines
}

\author{
Dr. Claire Kaplaan P. Lafadchan \\ Mountain Province State Polytechnic College \\ Bontoc Campus, Bontoc, Mountain Province
}

\begin{abstract}
This paper showcases the indigenous security measures practiced in Barangay Can-eo and Barangay Talubin at Bontoc, Mountain Province. This qualitative research used interviews in gathering data that were supported with library research. This study explored on the effectiveness and contributions of the ritualistic and nonritualistic security measures to individual safety and security of the community. It also exposes the relationship of the identified indigenous security measures to the Bontoc indigenous world view. It was found in the study that the ritualistic and non-ritualistic security measures in Barangay Can-eo and Barangay Talubin are effective and some are still being used and observed until today. The indigenous security measures are part of the relationship they have with nature, their environment and towards each other. It is a composite understanding and respect on how they deal with peace and order. It is concluded in this study that "Rituals emphasize the relationships between [Bontoc] farmers, the biophysical world, the social world and the supernatural world," June Prill-Brett (2016, 101-111). Despite the changing dynamics of safety and security in the present time due to the sophistication of technology, education and modernity, the indigenous security measures still exist in Barangays Can-eo and Talubin because of the deep-seated respect that the people demonstrate on the rituals and non-ritualistic symbols and archetypes. The indigenous security measures reinforce community trust in relation to property and individual protection as well as community fortification.
\end{abstract}

Keywords: indigenous security measures, sumang, Bontoc

\section{Introduction}

The Philippines is home to 110 indigenous groups, thirteen of which are found in the Cordillera Administrative Region whose practices and traditions vary to some degree. Of the total population in the nation, between $10 \%$ and $20 \%$ are estimated to belong to indigenous inhabitants(Dekdeken and Cariño 2016, 252). The Cordillera Administrative Region (CAR) in Northern Philippines is where the Igorots (ethnic groups living in the mountains of Northern Luzon) live; and Lumadsoccupy Southern Mindanao, with some groups in the Visayas area.

It is acknowledged that the indigenous groups have contributed to management and preservation of our natural resources. Today, the indigenous people continue to exhibit their skills in arts, music, dances and native knowledge ; holding on to their be lief and culture whichgivethem self-worth.

The government has recognized the roles of the indigenous groups in the country, there by the state passed the Indigenous People's Right Act of 1997, also known as RA 8371 to protect them of their rights and from exploitation. The practice and preservation of traditions in cultural communities is asserted in Section 29 of RA 8371 which is to protectindigenous culture, traditions and institutions advantageous to the cultural communities.

Among the twelve (12) ethno-linguistic groups in the Cordillera Administrative Region (CAR) is Bontokwhichsettles on the heart of Mountain Province with a population of 24, 643 as of 2015 (Philippine Statistics Authority 2017). Bontok is one of the indigenous groups in Cordillera that inhabits the Municipality of Bontoc in Mountain Province with a population of 24, 643 as of 2015 (Philippine Statistics Authority 2017). Manochon $(2009,52)$ mentioned that:

"...Wet rice cultivation is the main source of living in Bontoc. There are two crops in a year and they are called chinakhon and pak-ang. It is supplemented by other gainful activities as slash-and- 
burn farming, gardening, fishing, small business enterprises, and cottage industries such as textile weaving, basket weaving and pottery."

The Bontoc people, as an indigenous group, were able to resist the major influence of conquerors and maintained their pre-colonial beliefs and traditions. Hence, "before the governmenttook over the peace-keeping job in Bontoc, the Bontok people had theirownlaws of war to securetheirlives, clan and property" (Manochon 2009).

Prill-Brett $(2015,194)$ contends that, although formal education and western health practices were introduced in Bontoc, "indigenous customs governing natural resources management were largely left to the communities in Bontoc that continued to practice control over their indigenous political institutions and local resource management" through rituals, traditional practices, use of material culture and the observance of customary practices.

In the contemporary Bontoc society, Lang-ay festival (annual Mountain Province Agro-Industrial Fair) and Am-among festivals (Agro-industry Fair celebrated by the Municipality of Bontoc) are celebrated to showcase the local cottage industries. These festivals are also encouraging the participation of children to ensure that traditional culture ispassed on to the youngergeneration.

Among the sixteen (16) participating barangays to the celebrated Am-among Festival are Barangays Can-eo and Talubin which are distance a way from the modernity of Central Bontoc. Eight kilometers towards the western part is Barangay Can-eo and a little further is Barangay Talubin which is 12 kilometers from Bontoc Central. Residents of these two communities have retained some of their pre-colonial be lief system and practices, most especially in agriculture and socio-culture. The main source of livelihood in Can-eo and Talubin is farming wherein they plant rice and other crops alternately.

Looking at the crime statistics from year 2014 to 2016 Barangays Can-eo and Talubin has very low crime rate with only two (2) cases of theft at Talubin on 2015 from the total of 426 reported cases on the same year (Bontoc Municipal Police Station 2017). It is believed that the existence of the indigenous security measures in Can-eo and Talubin is linked with the almost zero crime rates.

Indigenous security measures are safety initiatives that directly or indirectly improve community safety. These are rituals, practices, material objects and protection symbols which help the community in ensuring safety and security from loss or damage.

This research is conceptualized to document the indigenous security measures; to delve into its effectiveness; and to establish how the indigenous security measures and their effectiveness tied to the indigenous worldview. It is important to explore the existing indigenous security measures since both barangays are still tangled in their social and agronomic practices and security needs to be attained through traditional means.

\section{Method}

\section{Participants}

The researcher team interviewed five (5) selected community elders from barangays Can-eo and Talubin. Elders (50-70 years old) who are known as experts on customary laws participated on the focus group discussion on September 3 and 5, 2014. The research team also conducted interviews among other key informants on June and July 2017 to augment testimonial evidences that were previously gathered. The results of the interviews and focus group discussion are limited on the experiences of the elders and their encounters with the effects of indigenous security measures. Their testimonies are also based on the belief sinculcated to them by theirfore fathers.

\section{Design}

Qualitative design wasused in this study sinceitsaimis to determine and document the existing security measures employed by the community membersat Barangays Can-eo and Talubin through descriptive analysis. 


\section{Materials}

The data gathered were validated through other testimonial evidences from other community members and elders from other barangays of Bontocwho observe similar indigenous security measures. Archival researchwas employed to support the findings of the study.

\section{Procedure}

Participants were interviewedat home and at the barangay halls where focus group discussions were held. The research team explained to the elders the nature and consequences of the research. Aftergiving their consent, interviews were carried out to gather the needed data. After the transcription and translation of the interview results, itwasshown to the participants for validation. The matic analysis wasused to treat the data which was supported by literatures and follow-up interviews.

\section{Results}

From the interviews and focus group discussions, the researchers were able to identify two categories of indigenous security measure. One is ritualistic which includes practices that require procedures, while the second is non-ritualistic which is signified by material objects and protection symbols.

These two categories are strongly tied to the principle of worldview, which Hart $(2010,2)$ describes as, “....cognitive, perceptual, and affective mapsthat people continuously use to makesense of the social landscape and to findtheirways to whatever goals theyseek."

The principle of respectful individualism, which captures the relational values of indigenous culture and the spiritual, healing aspects of helping relationship, is absorbed in the study. A respectful individualism implies that individual responsibility is everyone's collective responsibility. In this framework, the need to respect one's culture or belief and observing it through practice is indeed helpful in maintaining peace in the society. By just merely using indigenous security measures is already a sign of ownership over which the measure was applied. It also follows that not getting what is not yours is a sign of respect among other individuals.

Respectful individualism is reflected on the indigenous worldview in Can-eo and Talubin, specifically on ontology and anitism wherein the experiences of the people with their relationship with the environment is interpreted according to their beliefs. Anitism is echoed through traditional security measures being practiced in Can-eo and Talubin; their sense of protection consists of interplay of rituals and the use of amulets as protection symbols.

Bontoc people always believed that occurrences are associated with the intervention of gods and spirits which can affect the day-to-day course of existence in the community. One illustration of the Bontoc spirit world is the observance of rites pertaining to death, as mentioned by Respicio (1984), is a lucid display of their belief in the afterlife and the deep respect for the anitos. Saboy (2016) regarded anitos as dead, in the sense that they are spirits or disembodied beings; they are not part of the physical world, although they are regarded as being able to influence it. The belief, relationship and encounter of the Bontoc people with the unseen forces, anitos and existence of supreme deity allows them to establish their indigenous worldview on spirit world.

Another description of the Bontoc spirit world is the well-narrated prayers and rituals taught by Lumawig(the demigod who descended from Mount Kalawitan and lived with the people of Bontoc where he taught the Bontoks how to perform rituals and practice traditions) in all occasions. Today, ritualistic and nonritualistic security measures can be conduits of the supernatural.

\section{Discussion}

\section{Ritualistic Security Measures}

As defense, rituals are beingpracticed and observed in Can-eo and Talubin to keep their community from harm, illness and to keep the luck. The following are practices observed in Can-eo and Talubin to keep their community and properties safe.

1. Tengaw (rest day). Literally, tengawis understood among the Bontok people as a rest day but it is practiced according to purpose. In this study, tengaw means the sacredness of the ritual performed by the elders, whether 
due to burial of the dead, observance of the agricultural calendar or the mere reason that it is forbidden for anybody to go to the fields. As a restday, tengawisobservedafter the elders gatherat the atothen they disperse to different path ways to place the puchongwhichwillsignify the start of the tengaw. Anyone whoviolatesthis practice willbefined based the customary laws. Generally, tengawis practiced to ask the gods some favor of good harvest and good health.

Tengawis observed after the elders perform a ritual wherein elders gather at the papattay (sacred place of worship usually marked by a big tree) to chant prayers and cook a chicken as offering to those they consider as heroes in the past. After the ritual, tengaw it is signified by placing puchong on the community entrance to inform all residents about the ritual. "The natives strongly believe that bad luck will come if this is ignored," said Edwin Amok of Can-eo during an interview conducted by the researchers last September 3, 2014.

Tengaw, according to Dr. Fiar-od (2007) are shown with signs and symbols usually found in community entry sites, in fields or in houses, which means "No Entry" or no entering in the community when local holidays (tengaw, obaya) are observed.

2. Pa-ang. During the focus group discussion with the researchers last September 5, 2014, Joe Napaeg said that pa-angis a practice in their place with the belief that colds (illness) will not enter their community. This is done in the form of tengaw after a ritual in the ato. They pierce the skull of a butchered dog and hangitat the entrance of their barangay. This cautions anyone fromgoing in, so that they will not bring badluck, or going out of the community to takeaway good luck. Pa-angis more of a tradition but the skull of the dog is a sign of the activity which conveys a warning to people.

3. Puchong. Apiece of fresh stick with a slab of meattied to it (Bacwaden 2008) isused to warnintruders from tresspassing and theft. It can also beleavesor grasstied in a knot and stuck in a stick, as stated by the elders namely Manuel Onga-ong, Peter Ached and Edwin Amok of Can-eo during the focus group discussion on September 3, 2014. Before the puchong is placed near a property "kapya" (prayer chanting after cooking chicken as offering) is performed first. Puchongis a symbol which means no trespassing and if is placed in front of the house, it means no entry. In her lecture among tourists in Mountain Province, Fiar-od (2002) emphasized that if puchong is disregarded the one who insisted on a trip will encounter misfortune such as vehicular accidents or even death. This secures belongings from loss, damage and prevents theft. It is placed near properties to warn and deter other people from touching and getting the property. It is also placed near the pathways to warn people from going to the fields during tengaw.

4. Apoy. It is a ritual practice in Talubin to protect their allang (rice granary) from insect, animals and thieves. This is done by an elder who makes a small fireplace near the granary and boils a piece of salted meat. Later on, the elder chants a prayer, asking Lumawigand spirits to protect the rice grains inside the structure.

\section{Non-Ritualistic Security Measures}

The following are material cultures such as amulets, material objects and protection symbols that are being used by the community members of Can-eo and Talubin to ward off evil, cure ailments and to protect themselves from harm.

1. Sumang(talisman). In general, sumang can be anything that is believed to give protection from harm. In this study, it comes in a form of a necklace comprised of dried piece of bark, dried root and black basalt. The sumang, according to the two elders of Can-eo named Manuel Onga-ong and Peter Ached of Can-eo who were interviewed by Jordan Chakas, a member of the research team, on September 3, 2014, is composed of chalaw, chutor, fab-an si kimat and sublay (see Figure 1). The purpose of this physical charm is to counter the effects of padpadya (witchcraft) and to warn the wearer from kiwachay (poison). 


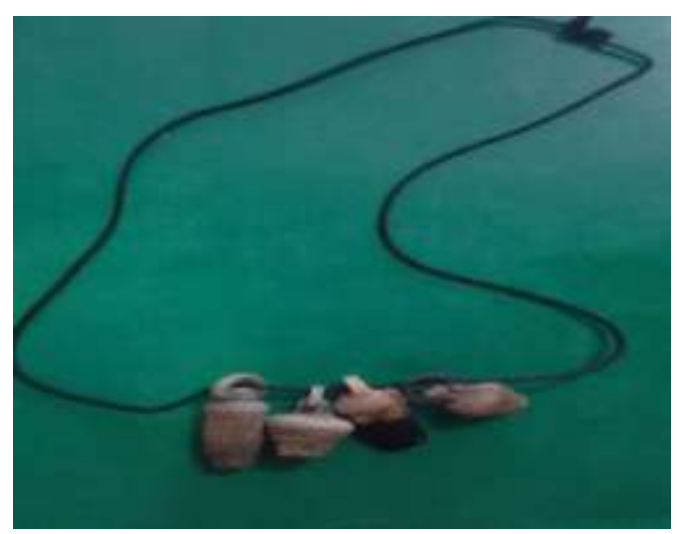

Figure 1.

A sumang worn by one of the elders who were interviewed.

2. Chalaw. "Chalaw is a root and looks like a thin vine which produces a fragrant odor when pierced or cut" (see Figure 2), said Edwin Amok, an elder of Can-eo who was interviewed by the researchers on September 3, 2014. It is sliced to small pieces the size of beads then worn as a necklace to prevent a person from having nightmares because of its soothing aroma. It also acts as a dream catcher since it is believed to block-off nightmares and allow the user to dream of beautiful things. This is usually paired with Chutor and it is a valuable ingredient for Sumang because of its strong fragrance.

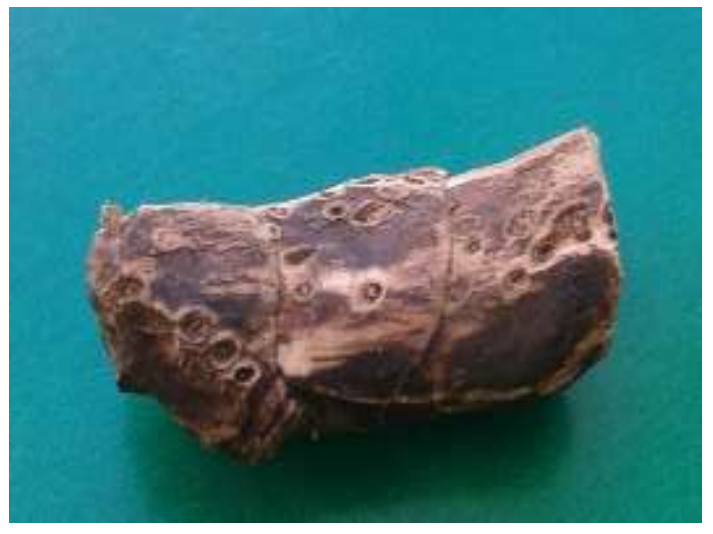

Figure 2. Dried root of he chalaw plant.

3.Chutor. A root that looks like a ginger, chutor also produces a fragrant smell when pinched or sliced, according to the three elders of Can-eo namely Manuel Onga-ong, Peter Ached and Edwin Amok who were interviewed by the researchers on September 3, 2014 (see Figure 3). This is used as a dream catcher since it is believed that children who wear will not have nightmares. It is also used to drive away evil spirits because the fragrance will protect the wearer. When paired with chalaw and sumang, the fragrance is stronger and so with the protection it provides the wearer. 


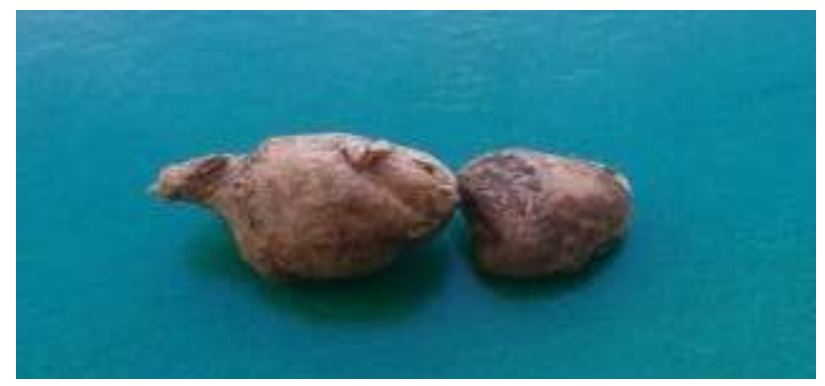

Figure 3.

Dried root of chutorused by one of the eldersfromTalubin.

4. Fab-an si kimat. It is a cuspid-shaped black basaltwhichis, according to Peter Ached of Can-eo who was interviewed by the researchers, is found on places that are struck by lightning (see Figure 4). He further said that this element is very hard to find because it literally chooses its owner in a way that it shows itself only to the chosen few. Though there are items sold in the streets, people from Talubin and Can-eo prefer the basalts they personally found since they believe that it gives them luck. This is used to cure dog and snake bites. The basalt is tied to the bite wound until it absorbs the venom or rabies which usually takes a day or so. After the healing process, the basalt is soaked in milk to regain its healing power. Mr. Roy Bawiyan, a resident of Talubin, interviewed by Claire Kaplaan P. Lafadchan on June 21, 2017, remarked that "Milk is used to remove the toxins absorbed by the black basalt from snake bites and wounds, thereby renewing its power." In Siquijor, an islandlocated in Central Visayas in the Philippines, this black basalt, alongwithotherherbs, isalsoused to ward off evil spirits (Sochaczewski 2001).

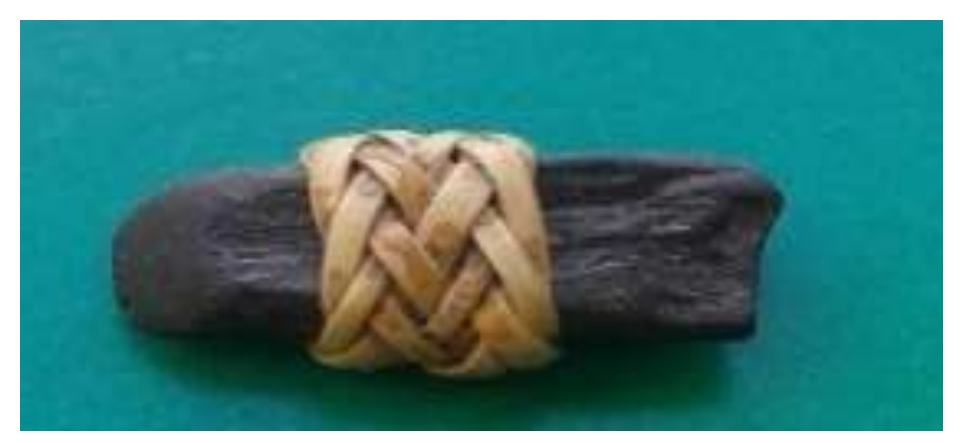

Figure 4.

Fab-an si kimatused as a necklace by one of the researchers.

5. Sublay. A piece of wood bark from a withered tree. According to Joe Napaeg, a participant of the focus group discussion with the researchers in Talubin on September 5, 2014, this is a stand-alone sumang because it has a strong fragrance (see Figure 5). This warns the wearer from kiwachay,protects the wearer from misfortunes and cure stomachache (commonly loose bowel movement), slight fever and malaria. To cure a stomach ache (or loose bowel movement), slight fever and malaria, the wearer will scratch some pieces of sublay and mix it with a cup of water and drink it. Some chew the sublay and swallow it even if it is bitter. 


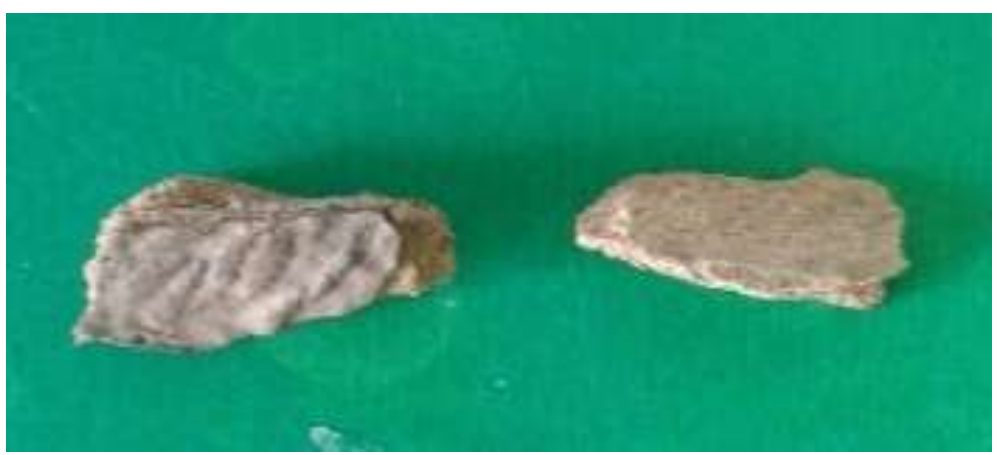

Figure 5.

This sublay is a part of the collection of the sumang carried by one of the elders from Can-eo.

Practical and Anecdotal Evidence

The following are anecdotal evidences on the practical applications of the indigenous security measures.

\section{Sumang}

In an interview by the researchers with Mr. Gregorio in Barangay Talubin on September 5, 2014, he narrated his experience with his two (2) friends and one from Maligcong. They went to the market to drink some liquor. Then an old folk from Bontoc passed by and Mr. Gregorio called for him to drink with them. The old folk from Bontoc tossed then filled the glass again. He gave it to Mr. Gregorio with his thumb dipped in the glass (his thumb contained kiwachay or poison). After that, the man from Bontoc left immediately. When Mr. Gregorio was about to drink the liquor, the glass suddenly shattered to pieces. All of them were shocked, and at that time Mr. Gregorio was carrying with him a sumang. From this story, it implies that sumang is a protection from harm to the person who carries it.

\section{Chalaw}

In an interview with Mr. Edwin Amok on September 5, 2014 by the researchersat Can-eo, he said that chalaw is effective as a dream catcher and a protection to drive evil spirits away. In another interview last September 3, 2014 with Joseph who grew up from Talubin, he narrated the story about how the chalaw helped him regain good sleep after a nightmare. He said that several times he woke up from a nightmare and pinched the chalaw necklace. He smells the good odor that is coming from the dried root, after which, he was sleep well. He even said that he always use the chalaw.

\section{Chutor}

During the focus group discussion last September 5, 2014 with the three elders of Can-eo namely Manuel Onga-ong, Peter Ached and Edwin Amok, they claim that chutor can also be used as a dream catcher; protection of properties, and a valuable ingredient for a sumang. They say that chutor is an effective means of protecting one's properties such as money, jewelries and other valuables. It can also be used to protect oneself from harm or untoward incidents. During an interview with Mr. Amok Nadcop, an elder from Barangay Samoki last June 21, 2017, he recounted his experiences of using chutor to cure his stomach ache. He said that chutor is roasted over fire to make it warm before it will be crushed and mixed with oil. The concoction is then rubbed into the stomach which works like a topical ointment, relieving the pain.

\section{Fab-ansikimat}

Fab-ansikimat (a black basalt believed to be tooth of the lightning). According to an elder from Can-eo, this charm gives luck to travellers who possess them. Sometimes it is like a double-edged sword because it will attract trouble if the owner has a corrupt personality; thus, people with negative intents do not usually carry with them this kismet.

\section{Sublay}

According to Peter Ached of Can-eo, the effectiveness of sublay was proven from the experiences of their people. They narrated the story wherein one of their elder was once given a poisoned beverage. When they visited another place, he received a bottle of the said drink but then it suddenly broke to four pieces, which led them to believe that that drink was poisoned and because their elder was carrying with him his "sublay", he was prevented from drinking the poison. Sublay is also used to cure stomach ache. Its usual doze is drinking five pieces of sublay for three times a day. In other barangays of Bontoc such as Bontoc Ili and Samoki, sublay is given to children who have diarrhea and loose bowel movement.

It has been claimed by many that sublay works like synthetic medicine since it cures stomach ailment. 
According to Mr. Amok Nadcop, an elder from Barangay Samoki who was interviewed last June 21, 2017 by the author, he explained that five to seven (5-7) pieces of sublayis swallowed by an adult experiencing stomach ache or diarrhea while three to five (3-5) pieces is given to children.

\section{Puchong}

In an interview with Mr. Gregorio on September 5, 2014 with the researchers, the elder from Talubin narrated a story about a man named Ponga who planted camote (sweet potato) leaves in Agyu and at the center of his rice field he put a "puchong". He prayed to Lumawig, the source of protection and blessings, that anyone who gathers his crops without his permission, the thief will suffer the pains of boil. One day there were three ladies from Bontoc who went to Agyu and they saw the rice field of Ponga that was full of camote leaves. They gathered some without noticing the puchong at the center. The following morning the three ladies from Bontoc cannot walk normally because there were boils grown in between their thighs. They immediately went to Talubin and consulted a seer, and it was found out that the cause of the boils was the act of gathering camote leaves at Agyu. The three ladies were accompanied by the seer to visit Mr. Ponga. They offered him sugar and admitted that they were the ones who gathered the camote leaves. Before sundown the boils were gone.

In a separate interview with GeralvinTiyoc, a college student from Talubin, on September 7, 2014, narrated a story about how he tested the effectiveness of puchong. He said that they went to the fields and saw a ripe pineapple planted along the way. He harvested it despite the presence of puchong but when he came home, he felt a lump and pain on right leg. He inspected it and he saw that it was reddish and a small vuyoy(boil) is growing on the skin of his leg. "Kapapatigayamtipuchong ken vuyoy,"he said (Puchong and boil are indeed true).

7. Apoy

The elders of Talubin and Can-eo have similar claims on the effectiveness of practicing apoyisproven by the fact that theirricegranarieswereneverinfested with rats and insects. There were not evenattempts to rob the ricegranaries in the community. This ritualiscarried out by putting a smallfire in front of the door of the ricegranary and chanting prayers so that the unseen forces willguard the granary frompests and theft. Apoy, along with other Bontocrituals, is a "way of averting misfortune or away of curing an illness, and in deaths and calamities, a time to help a member of the family and community" (Manochon, 2009).

\section{Tengaw}

Tengaw is also observed to ask for protection from bad weather and any accident. According to Mr. Peter Ached from Can-eo, in an interview last September 3, 2014 by the researchers, community members who insisted to go to the fields despite the declaration of tengaw are normally fined because they do not respect the tradition. But then, the greater effect is when one is confronted with bad luck. Mr. Ached relayed a story about one woman who sneaked out from the community to check on her rice seedlings, disregarding tengaw. After a few days, the rice seedlings withered. A similar statement was made by Mr. Roy Bawiyan, a resident of Talubin, interviewed by Claire Kaplaan P. Lafadchan (one of the researchers) on June 21, 2017, "Residents are not allowed to get out of the community to keep the luck received from a good harvest, to ask the gods for protection, and to respect the ritual itself."

\section{Pa-ang}

In an interview with Mr. OngenBawiyan, an elder from Talubin, last June 21, 2017, he narrated that the sacredness of pa-angshould not be ignored since danger comes to those who do not heed. He further told a story about another community member who insisted to go to the field, despite the community observance on pa-ang, to check on the water irrigation but suddenly he tripped and broke his leg. This incident was regarded by the elders as bad luck since the victim ignored the observance of the pa-ang. The ato members and other community elders considered the incident as an exemplarity to prevent others from committing the same violation.

The indigenous security measures are practiced as part of the daily lives of the people of Can-eo and Talubin since they were able to come up with initiatives to protect their crops and produce from insects and thieves. The amulets or symbols of protections for personal well-being and the rituals they perform to defend the community from untoward incidents are effective means to ensure security. The low crime rate at Barangays Can-eo and Talubin can be a reflection of the efficacy of the existing indigenous security measures. The reverence on the beliefs is a factor in promoting community trust and a holistic attitude in community safety because of the respect they bestow to indigenous security measures as often practiced and observed.

The usefulness of the indigenous security measures is evidenced by the testimonies of the residents who experienced its effects. This can again be tied to the principle of indigenous worldview cited by Simpson (2000) which is "truths are dependent upon individual experiences." The stories are considered as proof as to 
why the indigenous security measures exist until today since it draws respect to the material culture and the culture as a whole.

From the perspective of the Bontok society, most specifically among the residents of Can-eo and Talubin, the material objects, protection symbols and ritauls are part of the worldview which brands them as Bontoks. The indigenous security measures are part of the relationship they have with nature, their environment and towards each other. It is a composite understanding and respect on how they deal with peace and order. The perspective on the belief of the indigenous security measures is important to the people of Can-eo and Talubin since their community activities still rely on their agricultural and socio-cultural calendar.

\section{Conclusion}

"Rituals emphasize the relationships between [Bontoc] farmers, the biophysical world, the social world and the supernatural world," June Prill-Brett (2016, 101-111). Despite the changing dynamics of safety and security in the present time due to the sophistication of technology, education and modernity, the indigenous security measures still exist in Barangays Can-eo and Talubin because of the deep-seated respect that the people demonstrate on the rituals and non-ritualistic symbols and archetypes. The indigenous security measures reinforce community trust in relation to property and individual protection as well as community fortification.

\section{References :}

Bacwaden.

Joy.

(2008.)

LumawigBontocMyths.

Philippine

Studies.

Retrievedfromphilippinestudies.net/ojs/index.php/ps/article/download/494/500.

[2] Dekdeken, Sarah and Carino, Jill. 2016. IWGIA - THE INDIGENOUS WORLD 2016.Retrievedfromhttp://www.igwa.ord/images/stories/sections/regions/asia/documents/IW2016/Philippines_IW2016_web_redu.pdf.

[3] Fiar-od, Caridad.(2007). Understanding the Igorot Culture: Giving Meaning to One'sVisit in Mountain Province.Lecture presented to guide tourists as part of the 2007 Lang-ay Week Celebration. This lecture is part of Lang-ay celebration at Bontoc on April 4, 2007.

[4] Hart, Michael. (2010). Indigenous Worldviews, Knowledge, and Research: The Development of an Indigenous Research Paradigm.Journals of Indigenous Voices in Social Work. Retrieved from http://www.hawaii.edu/sswork/jivsw/.

[5] Hart, M. A. (2002). Seeking mino-pimatisiwin: An Aboriginal approach to helping.Fernwood Publishing.Halifax,Nova Scotia, Canada.

[6] Manochon, Antonina M. (2010). Interpreting Selected Myths as Expression of BontocWorldview.College of Arts and Communication, University of the Philippines-Baguio.

[7] McKenzie, B., \&Morrissette, V. (2003). Social work practice with Canadians of Aboriginalbackground: Guidelines for respectful social work. In A. Al-Krenawi\& J. R. Graham (Eds.), Multicultural social work in Canada: Working with diverse ethno-racial communities (pp. 251-282). Don Mills, Ontario, Canada: Oxford University Press.

[8] Philippine Statistics Authority.(2015). Bontoc Municipality Population Census.

[9] Prill-Brett, June. (2016). Tradition and Transformation, Studies on Cordillera Indigenous Culture.Cordillera Studies Center.University of the Philippines-Baguio City.

[10] Respicio, Norma A. (1984). Death and Textiles in Bontoc Culture.Retrieved from http://www.ichcap.org/eng/ek/sub3/pdf_file/domain3/047_Death_and_Textiles_in_Bontoc_Culture.pdf

[11] Saboy, Scott M. (2016). Matatagu'nAnitu("Living Anito") as a Trope for Recontextualizing Tradition and Re/Presenting Indigeneity. Conference on Koolage, L. Simpson, \& N. Schuster (Eds.), Aboriginal health, identity and resources (pp. 165-185). Winnipeg, Manitoba, Canada: Native Studies Press.

[12] Sochaczewski, Paul Spencer. (2001). To Ward Off EvilSpririts, TrySome LightningTeeth. International Herald Tribune, May 2001. Retrievedfrom http://www.nytimes.com/2001/05/10/opinion/to-ward-off-evil-spirits-try-some-lightning-teeth.html 